\title{
Pemberian Tepung Daun Lamtoro (Leucaena leucocephala) Dalam Ransum Terhadap Kualitas Telur Burung Puyuh (Coturnix-coturnix Javonica)
}

\author{
Abu Hasan Ashari, Aisyah Nurmi ${ }^{2}$, Muharram Fajrin Harahap ${ }^{3}$ \\ ${ }^{1,2,3}$ Fakultas Peternakan Program Studi Peternakan Universitas Muhammadiyah Tapanuli \\ Selatan, e-mail :abuhasanashari@yahoo.com
}

\begin{abstract}
ABSTRAK
Lamtoro (Lecaena leucocephala) merupakan salah satu tanaman yang banyak sekali kita jumpai didaerah tropis termasuk di Indonesia dan cukup melimpah. Kandungan nutrisi yang terdapat dalam daun lamtoro yang cukup tinggi sehingga dapat dimanfaatkan untuk bahan campuran untuk ransum burung puyuh (Coturnix-coturnix jovanica). Penelitian ini bertujuan untuk mengetahui pengaruh penambahan tepung daun lamtoro dalam ransum terhadap berat telur, tebal kerabang, indeks kuning telur, indeks putih telur, haugh unit (HU) burung puyuh. Rancangan penelitian yang digunakan adalah Rancangan Acak Lengkap (RAL) dengan jumlah perlakuan $(\mathrm{t})=6$, ulangan $(\mathrm{n})=4$ dengan susunan perlakuan L0 0\%, L1 5\%, L2 10\%, L3 15\%, 20\%, L5 25. Dapat disimpulkan bahwa pemberian tepung daun lamtoro dalam ransum terhadap kualitas telur burung puyuh dengan pemberian tepung daun lamtoro sebanyak 5\%, 10\%, 15\%, 20\%, 25\% dengan perlakuan berbeda selama penelitian tidak memberikan pengaruh nyata terhadap berat telur, tebal kerabang telur, indeks kuning telur, indeks putih telur, haugh unit burung puyuh.
\end{abstract}

Kata Kunci : Tepung Daun Lamtoro, Burung Puyuh, Kualitas Telur.

\section{PENDAHULUAN}

Meningkatnya jumlah penduduk yang menyebabkan tingginya angka pengangguran menjadikan burung puyuh sebagai salah satu alternative usaha yang dinilai cukup menguntungkan karena dalam pemeliharaannya tidak tibutuhkan areal yang luas dan pengembalian modalnya relative cepat karena burung puyuh dapat menjapai dewasa kelamin sekitar umur 42 hari dengan produksi telur antara 250-300 butir/tahun (Listiyowati dan Roospitasari, 2000).

Dalam pemeliharaan burung puyuh (quail) pada mulanya kurangmendapat perhatian dari para peternak. Tetapi sejak pemerintah merencanakanburung puyuh sebagai salah satu alternatif untuk peningkatan penyediaan proteinhewani untuk masyarakat, barulah burung puyuh mulai terangkat namanya. Peternakpun mulai bergairah untuk mengembangkan ternak ini. 
Menurut Suprapti (2002), telur merupakan salah satu produk peternakan unggas yang memiliki kandungan gizi lengkap dan mudah dicerna.Telur merupakan salah satu sumber protein hewani disamping daging, ikan dan susu. Secara umum terdiri atas tiga komponen pokok,yaitu kulit telur atau cangkang (11 \% dari bobot tubuh),putih telur (57 \% dari bobot tubuh) dan kuning telur (32\% dari bobot tubuh).

Kualitas telur dapat digolongkan menjadi dua macam, yaitu kualitas telur bagian luar (eksterior) dan kualitas telur bagian dalam (interior).Kualitas telur interior meliputi indeks yolk (kuning telur), indeks albumen (putih telur),pH kuning eksterior meliputi bentuk telur, berat telur, kebrsihan kerabang.Penentuan secara dan putih telur, warna kuning telur dan keadaan rongga udara serta nilai Haugh Unit (Indratiningsih, 1996).

Penelitian ini bertujuan untuk melihat kualitas telurburung puyuh (Coturnix -coturnix javonica)dengan pemberian tepung daun lamtoro(Carica papaya $L$ ) dalam ransum.

\section{MATERI DAN METODE PENELITIAN}

\section{Materi Penelitian}

Penelitian ini telah dilaksanakan dikandang aneka ternak Mix Farming Experience (MFE) Fakultas Peternakan Universitas Muhammadiyah Tapanuli Selatan selama enam minggu, mulai dari bulan Januari sampai dengan Maret 2017.Ternak yang digunakan adalah burung puyuh betina umur satu hari sampai bertelur sebanyak 120 ekor. Sampel diambil dari populasi puyuh yang diperoleh daripoultry shop, dilakukan pengacakan ditempatkan lima ekor setiap petak diberi tanda sesuai pelakuan. Kandang yang digunakan sebanyak 24 petak dengan ukuran $30 \times 30 \times 30 \mathrm{~cm}$ diisi lima ekor puyuh/plot.Alat yang digunakan dalam penelitian ini timbangan elektrik, jangka sorong, dan yolk colour fan. Bahan yang digunakan dalam penelitian ini adalah ransum berdasarkan perlakuan, vaksin dan obat - obatan, sertadesinfektan (rhodalon).

\section{Metode Penelitian}

Rancangan yang digunakan adalah Rancangan Acak Lengkap (RAL) dengan jumlah perlakuan $(\mathrm{t})=4$, ulangan $(\mathrm{n})=6$.

Adapun susunan perlakuan ransum adalah sebagai berikut :

L0 = Ransum tanpa pemberian tepung daun pepaya (0\%)

L1 = Ransum dengan pemberian tepung daun lamtoro (5\%)

L2 = Ransum dengan pemberian tepung daun lamtoro (10\%)

L3 = Ransum dengan pemberian tepung daun lamtoro (15\%)

L4 = Ransum dengan pemberian tepung daun lamtoro (20\%) 
L5 = Ransum dengan pemberian tepung daun lamtoro (25\%)

\section{Ransum}

Pencampuran ransum dilakukan setiap seminggu sekali sesuai perlakuan. Perlakuan diberikan setelah DOQ berumur 6 hari. Bahan penyusun ransum terdiri dari tepung ikan, jagung kuning, dedak padi, bungkil kedelai, ampas tahu, minyak sawit, mineral, dan tepung daun lamtoro sesuai dengan perlakuan.

Tabel 1. Kandungan nutrisi makanan penyusun ransum penelitian

\begin{tabular}{lllllll}
\hline Bahan Pakan & $\begin{array}{l}\text { Protein } \\
(\%)\end{array}$ & $\begin{array}{l}\text { EM } \\
(\text { Kkal/Kg) }\end{array}$ & $\begin{array}{l}\text { Lemak } \\
(\%)\end{array}$ & $\begin{array}{l}\text { Serat } \\
\text { Kasar (\%) }\end{array}$ & Ca (\%) & P (\%) \\
\hline Jagung Kuning & 8,79 & 3300 & 3,8 & 2,5 & 0,01 & 0,13 \\
Dedak Padi & 13 & 1900 & 5 & 12 & 0,06 & 0,8 \\
Bungkil Kedelai & 42 & 2550 & 0,5 & 3 & 0,2 & 0,33 \\
Tepung Ikan & 55 & 2750 & 2 & 1 & 6,5 & 4 \\
T.Daun Lamtoro & 34,57 & 4701 & 2,23 & 19,61 & 0,47 & 0,79 \\
Ampas Tahu & 23,39 & 393 & 9,96 & 19,44 & 19 & 29 \\
Minyak Sawit & 0 & 8000 & 100 & 0 & 0 & 0 \\
Mineral & 0 & 0 & 0 & 0 & 0,17 & 0,3 \\
\hline
\end{tabular}

Tabel 2. Susunan ransum selama penelitian fase starter (0-3 minggu)

\begin{tabular}{lcccccc}
\hline \multicolumn{1}{c}{ Bahan Pakan } & \multicolumn{7}{c}{ Perlakuan } \\
& L0 & L1 & L2 & L3 & L4 & L5 \\
\hline Tepung Jagung (\%) & 32 & 32 & 33 & 33 & 32 & 32 \\
Dedak Padi (\%) & 15 & 15 & 12 & 11 & 11 & 11 \\
Bungkil Kedelai (\%) & 32 & 28 & 25 & 24 & 20 & 15 \\
Tepung Ikan (\%) & 5 & 5 & 5 & 5 & 5 & 5 \\
Minyak Sawit (\%) & 1 & 1 & 1 & 1 & 1 & 1 \\
Ampas Tahu (\%) & 14 & 13 & 13 & 10 & 10 & 10 \\
T. Daun Lamtoro (\%) & 0 & 5 & 10 & 15 & 20 & 25 \\
Mineral (\%) & 1 & 1 & 1 & 1 & 1 & 1 \\
\hline Jumlah (\%) & $\mathbf{1 0 0}$ & $\mathbf{1 0 0}$ & $\mathbf{1 0 0}$ & $\mathbf{1 0 0}$ & $\mathbf{1 0 0}$ & $\mathbf{1 0 0}$ \\
\hline EM (KKal/kg) & 2429,52 & 2558,64 & 2693,19 & 2871,95 & 2972,00 & 3079,55 \\
Protein (\%) & 24,23 & 24,04 & 24,21 & 24,69 & 24,65 & 24,27 \\
Lemak (\%) & 4,62 & 4,61 & 4,60 & 4,35 & 4,41 & 4,49 \\
Serat Kasar (\%) & 4,56 & 4,71 & 4,86 & 5,59 & 6,02 & 6,33 \\
Kalsium (\%) & 3,06 & 2,89 & 2,90 & 2,35 & 2,37 & 2,38 \\
Posfor (\%) & 4,53 & 4,26 & 4,27 & 3,43 & 3,45 & 3,48 \\
\hline
\end{tabular}

Tabel 3.Susunan ransum selama penelitian fase grower ( 3-5 minggu)

\begin{tabular}{lllllll}
\hline \multirow{2}{*}{ Bahan Pakan } & L0 & L1 & L2 & L3 & L4 & L5 \\
\hline
\end{tabular}




\begin{tabular}{lcccccc}
\hline Tepung Jagung (\%) & 35 & 35 & 35 & 35 & 33 & 28 \\
Dedak Padi (\%) & 18 & 16 & 15 & 15 & 15 & 19 \\
Bungkil Kedelai (\%) & 30 & 26 & 23 & 20 & 17 & 13 \\
Tepung Ikan (\%) & 5 & 5 & 5 & 5 & 5 & 5 \\
Minyak Sawit (\%) & 1 & 1 & 1 & 1 & 1 & 1 \\
Ampas Tahu (\%) & 10 & 11 & 10 & 8 & 8 & 8 \\
T. Daun Lamtoro (\%) & 0 & 5 & 10 & 15 & 20 & 25 \\
Mineral (\%) & 1 & 1 & 1 & 1 & 1 & 1 \\
\hline Jumlah (\%) & $\mathbf{1 0 0}$ & $\mathbf{1 0 0}$ & $\mathbf{1 0 0}$ & $\mathbf{1 0 0}$ & $\mathbf{1 0 0}$ & $\mathbf{1 0 0}$ \\
\hline EM (Kkal/Kg) & 2518,80 & 2617,78 & 2753,4 & 2904,09 & 2996,64 & 3040,69 \\
& & & 0 & & & \\
Protein (\%) & 23,11 & 23,13 & 23,23 & 23,23 & 23,53 & 23,65 \\
Lemak (\%) & 4,48 & 4,57 & 4,51 & 4,41 & 4,43 & 4,53 \\
Serat Kasar (\%) & 4,98 & 4,74 & 4,88 & 5,36 & 5,76 & 5,93 \\
Kalsium (\%) & 2,30 & 2,50 & 2,33 & 1,97 & 1,99 & 2,00 \\
Posfor (\%) & 3,39 & 3,69 & 3,42 & 2,87 & 2,90 & 2,95 \\
\hline
\end{tabular}

Tabel 4. Susunan ransum selama penelitian fase finisher ( $>5$ minggu)

\begin{tabular}{lcccccc}
\hline \multicolumn{1}{c}{ Bahan Pakan } & \multicolumn{7}{c}{ Perlakuan } \\
& L0 & L1 & L2 & L3 & L4 & L5 \\
\hline Tepung Jagung (\%) & 38 & 38 & 38 & 38 & 31 & 26 \\
Dedak Padi (\%) & 25 & 22 & 22 & 22 & 25 & 29 \\
Bungkil Kedelai (\%) & 25 & 25 & 20 & 15 & 12 & 7 \\
Tepung Ikan (\%) & 5 & 5 & 5 & 5 & 5 & 5 \\
Minyak Sawit (\%) & 1 & 1 & 1 & 1 & 1 & 1 \\
Ampas Tahu (\%) & 5 & 3 & 3 & 3 & 4 & 5 \\
T. Daun Lamtoro (\%) & 0 & 5 & 10 & 15 & 20 & 25 \\
Mineral (\%) & 1 & 1 & 1 & 1 & 1 & 1 \\
\hline Jumlah (\%) & $\mathbf{1 0 0}$ & $\mathbf{1 0 0}$ & $\mathbf{1 0 0}$ & $\mathbf{1 0 0}$ & $\mathbf{1 0 0}$ & $\mathbf{1 0 0}$ \\
\hline EM (Kkal/Kg) & 2603,65 & 2773,84 & 2881,39 & 2988,94 & 2977,42 & 2999,90 \\
Protein (\%) & 21,01 & 21,88 & 21,51 & 21,14 & 21,61 & 21,56 \\
Lemak (\%) & 4,42 & 4,18 & 4,27 & 4,35 & 4,43 & 4,63 \\
Serat Kasar (\%) & 4,67 & 4,97 & 4,82 & 4,96 & 5,36 & 5,72 \\
Kalsium (\%) & 1,34 & 0,99 & 1,00 & 1,01 & 1,22 & 1,43 \\
Posfor (\%) & 1,98 & 1,42 & 1,44 & 1,46 & 1,80 & 2,14 \\
\hline
\end{tabular}

\section{HASIL DAN PEMBAHASAN}

\section{Bobot Telur}

Telur pertama ditimbang berat telur puyuhnya setelah burung puyuh tersebut bertelur dengan menggunakan timbangan elektrik.Berikut ini rata-rata berat telur burung puyuh (Coturnix-coturnix javonica) pada masing-masing perlakuan dapat dilihat pada tabel dibawah ini.

Tabel 5.Rata- rata bobot telur burung puyuh pada masing-masing perlakuan (gram)

\begin{tabular}{ccccccccc}
\hline \multirow{2}{*}{ Ulangan } & \multicolumn{9}{c}{ Perlakuan } & \multirow{2}{*}{ Rataan } \\
\cline { 2 - 6 } & L0 & L1 & L2 & L3 & L4 & L5 & & \\
\hline
\end{tabular}




\begin{tabular}{ccccccccc}
\hline 1 & 9.27 & 8.53 & 9.17 & 8.83 & 8.83 & 7.95 & 51.70 & 8.62 \\
2 & 9.65 & 7.85 & 9.26 & 8.72 & 8.72 & 7.78 & 51.04 & 8.51 \\
3 & 8.38 & 8 & 8.51 & 9.83 & 9.83 & 9.15 & 53.02 & 8.84 \\
4 & 8.67 & 7.8 & 8.58 & 9.43 & 9.43 & 9.49 & 53.46 & 8.91 \\
\hline Total & 35.97 & 32.18 & 35.52 & 36.81 & 36.81 & 34.37 & 209.22 & 34.87 \\
Rataan & 8.99 & 8.05 & 8.88 & 9.20 & 9.20 & 8.59 & 52.31 & 8.72 \\
\hline
\end{tabular}

Dari tabel diatasbisa dilihat bahwarataan berat telur yaitu 8.72, dan perlakuan tertinggi ada pada perlakuan L3 dan L4 yaitu 9.20 gram. Dan perlakuan terendah yaitu pada perlakuan L1 sebesar 8.05.Hal ini berarti pemberian tepung daun lamtoro berpengaruh tidak nyata terhadap berat telur ini disebabkan karena pemberian tepung daun lamtoro bukanlah faktor utama yang bisa mempengaruhi pada berat telur sedangkan berat badan juga akan berpengaruhi terhadap berat telur, hal ini sesuai dengan pernyataan Etches (1996), menyatakan bahwa berat telur dipengaruhi oleh faktor genetic, berat badan, bibit, umur berat telur dan temperature lingkungan. Ditambahkan oleh Listiyowati dan Roosfitasari (1992) menyatakan bahwa bobot telur puyuh rata-rata10gr/butir atau sekitar 8\% dari bobot tubuh betina.

\section{Tebal Kerabang Telur}

Tebal kerabang telur merupakan salah satu faktor yang mempengaruhi kualitas telur, karena kerabang dapat melindungi isi telur. Ketebalan kerabang telur banyak dipengaruhi oleh kadar kalsium dalam ransum yang akan menentukan ketersediaan garam-garam.Berikut Rataan hasil pengamatan tebal kerabang telur burung puyuh selama penelitian terlihat pada Tabel dibawah ini.

\section{Tabel 6. Nilai Rataan Tebal Kerabang Telur Selama Penelitian (mm)}

\begin{tabular}{|c|c|c|c|c|c|c|c|c|}
\hline \multirow{2}{*}{ Ulangan } & \multicolumn{6}{|c|}{ Perlakuan } & \multirow{2}{*}{ Total } & \multirow{2}{*}{ Rataan } \\
\hline & $\mathrm{L} 0$ & L1 & $\mathrm{L} 2$ & L3 & $\mathrm{L} 4$ & L5 & & \\
\hline 1 & 1.00 & 1.00 & 1.00 & 1.00 & 0.99 & 0.94 & 5.93 & 0.99 \\
\hline 2 & 0.99 & 1.00 & 1.00 & 1.00 & 0.97 & 1.00 & 5.96 & 0.99 \\
\hline 3 & 1.00 & 0.99 & 1.00 & 0.99 & 1.00 & 1.00 & 5.98 & 1.00 \\
\hline 4 & 0.98 & 0.99 & 1.00 & 0.99 & 1.00 & 0.98 & 5.94 & 0.99 \\
\hline Total & 3.97 & 3.98 & 4.00 & 3.98 & 3.96 & 3.92 & 23.81 & 3.97 \\
\hline Rataan & 0.99 & 1.00 & 1.00 & 1.00 & 0.99 & 0.98 & 5.95 & 0.99 \\
\hline
\end{tabular}

Rataan tebal kerabang telur sebesar $0.99 \mathrm{~mm}$, sedangkan perlakuan tertinggi ada pada L1, L2, dan L3 yaitu pada rataan $1 \mathrm{~mm}$ dan perlakuan terendah pada L5 dengan rataan 0.98. Hal ini disebabkan karena ransum pada setiap perlakuan memiliki kalsium yang sedikit sehingga tidak berpengaruh pada ketebalan kerabang telur burung puyuh. Perbedaan ketebalan kualitas 
kerabang telur dipengaruhi oleh kandungan kalsium dalam ransum ransum seperti yang diungkapkan Stadelman and Cotterill (1995), kualitas kerabang telur ditentukan oleh besarnya kandungan kalsium dalam ransum, hal ini disebabkan karena 94\% bagian kerabang telur adalah kalsium karbonat.

\section{Yolk Indeks (Kuning Telur)}

Salah satu cara untuk mengukur nilai kualitas kuning telur dilakukan dengan menggunakan indeks kuning telur, yaitu membandingkan antara tinggi dengan diameter kuning telur. Pengukuran indeks kuning telur relatif lebih mudah dibandingdengan putih telur, karena bentuk kuning telur relatif lebih stabil dibanding putih telur.Berikut ini rata-rata yolk indeks telur burung puyuh (Coturnix coturnixjavonica) pada masing-masing perlakuan dapat dilihat pada tabel dibawah ini.

Tabel 7. Rata-rata yolk indeks telur burung puyuh pada masing-masing perlakuan.

\begin{tabular}{|c|c|c|c|c|c|c|c|c|}
\hline \multirow{2}{*}{ Ulangan } & \multicolumn{6}{|c|}{ Perlakuan } & \multirow{2}{*}{ Jumlah } & \multirow{2}{*}{ Rataan } \\
\hline & L0 & L1 & $\mathrm{L} 2$ & L3 & L4 & L5 & & \\
\hline 1 & 1.22 & 0.73 & 0.73 & 0.73 & 0.73 & 0.73 & 4.87 & 0.81 \\
\hline 2 & 1.11 & 0.79 & 0.79 & 0.61 & 0.6 & 0.6 & 4.5 & 0.75 \\
\hline 3 & 0.66 & 0.67 & 0.67 & 0.56 & 0.61 & 0.61 & 3.78 & 0.63 \\
\hline 4 & 0.58 & 0.61 & 0.61 & 0.53 & 0.73 & 0.73 & 3.79 & 0.63 \\
\hline Total & 3.57 & 2.8 & 2.8 & 2.43 & 2.67 & 2.67 & 16.94 & 2.82 \\
\hline Rataan & 0.89 & 0.70 & 0.70 & 0.60 & 0.66 & 0.66 & 4.23 & 0.70 \\
\hline
\end{tabular}

Pada Tabel 7 Terlihat bahwa rataan indeks kuning telur selama penelitian sebesar 0.70 dengan masing-masing perlakuan mempunyai rataan, perlakuan L0 (Ransum tanpa penambahan tepung daun lamtoro 0\%) dengan rataan indeks kuning telur $0.89 \mathrm{~cm}$, perlakuan L1 (Ransum dengan penambahan tepung daun lamtoro 5\%) dengan rataan indeks kuning telur $0.70 \mathrm{~cm}$, L2 (Ransum dengan penambahan tepung daun lamtoro 10\%) dengan rataan indeks kuning telur $0.70 \mathrm{~cm}$, perlakuan L3 (Ransum dengan penambahan tepung daun lamtoro 15\%) dengan rataan indeks kuning telur $0.60 \mathrm{~cm}$, perlakuan L4 (Ransum dengan penambahan tepung daun lamtoro 20\%) dengan rataan indeks kuning telur $0.66 \mathrm{~cm}$, perlakuan L5 (Ransum dengan penambahan tepung daun lamtoro 25\%) dengan rataan indeks kuning telur $0.66 \mathrm{~cm}$.

Hal ini disebabkan oleh pengaruh pemberian tepung daun lamtoro pada perlakuan L0 tanpa pemberian tepung daun lamtoro dibandingkan dengan perlakuan L5.Mempengaruhi indeks kuning telur yang menurun sehingga angka tinggi dan lebar indeks kuning telur juga menurun.Selain itu disebabkan oleh ransum yang diberikan pada burung puyuh tidak sepenuhnya habis dikonsumsi. 
Kuning telur bagian paling penting yaitu bagian dalam telur, sebab pada bagian inilah tempat tumbuhnya embrio, khususnya pada telur yang pertil (dibuahi). Menurut Stadelman and Cotterill (1995), kuning telur mempunyai rataan persentase 27,50\% dari bobot telur utuh.

\section{Albumen Indeks (putih telur)}

Putih telur terdiri dari empat bagian, berturut-turut dari bagianluar sampai bagian dalam lapisan putih telur encer bagian luar, lapisan putih telur kental bagian luar, lapisan putih telur encer bagian dalam, dan lapisan calazaferous. Lapisan calazaferous. Merupakan lapisan tipis yang kuat yang mengelilingi kuning telur dan membentuk ke arah dua sisi yang berlawanan membentuk calaza (Buckle et, al, 1987).

Berikut ini rata-rata albumen indeks telur burung puyuh (Coturnix coturnix javonica) pada masing-masing perlakuan dapat dilihat pada tabeldibawah ini

Tabel 8. Rata-rata putih telur burung puyuh pada masing-masing perlakuan

\begin{tabular}{|c|c|c|c|c|c|c|c|c|}
\hline \multirow{2}{*}{ Ulangan } & \multicolumn{6}{|c|}{ Perlakuan } & \multirow{2}{*}{ Total } & \multirow{2}{*}{ Rataar } \\
\hline & L0 & L1 & $\mathrm{L} 2$ & L3 & $\mathrm{L} 4$ & L5 & & \\
\hline 1 & 0.23 & 0.19 & 0.22 & 0.17 & 0.22 & 0.22 & 1.25 & 0.20 \\
\hline 2 & 0.15 & 0.17 & 0.24 & 0.17 & 0.21 & 0.21 & 1.16 & 0.19 \\
\hline 3 & 0.26 & 0.2 & 0.3 & 0.2 & 0.2 & 0.2 & 1.36 & 0.22 \\
\hline 4 & 0.22 & 0.28 & 0.21 & 0.22 & 0.21 & 0.21 & 1.41 & 0.23 \\
\hline Total & 0.86 & 0.84 & 0.97 & 0.76 & 0.84 & 0.91 & 5.18 & 0.86 \\
\hline Rataan & 0.22 & 0.21 & 0.24 & 0.19 & 0.21 & 0.23 & 1.29 & 0.21 \\
\hline
\end{tabular}

Dari tabel terlihat bahwa rataan indeks putih telur selama penelitian sebesar $0.21 \mathrm{~cm}$. Rataan pada perlakuan L0 (Ransum tanpa penambahan tepung daun lamtoro 0\%) dengan rataan indeks putih telur $0.22 \mathrm{~cm}$, perlakuan L1 (Ransum dengan pemberian tepung daun lamtoro 5\%) dengan rataan indeks putih telur 0.21, perlakuan L2 (Ransum dengan pemberian tepung daun lamtoro 10\%) dengan rataan indeks putih telur $0.24 \mathrm{~cm}$, perlakuan L3 (Ransum dengan pemberian tepung daun lamtoro 15\%) dengan rataan indeks putih telur $0.19 \mathrm{~cm}$, perlakuan L4 (Ransum dengan pemberian tepung daun lamtoro 20\%) dengan rataan indeks putih telur 0.21 cm, perlakuan L5 (Ransum dengan pemberian tepung daun lamtoro 25\%) dengan rataan indeks putih telur $0.23 \mathrm{~cm}$. Rataan indeks putih telur paling rendah pada perlakuan L3 (Ransum dengan pembrian tepung daun lamtoro 15\%) sebesar $0.19 \mathrm{~cm}$.

Hasil ini menunjukkan berbeda tidak nyata ( $\mathrm{P}>0.05$ ), tinggi rendahnya indeks putih telur burung puyuh disebabkan oleh pemberian tepung daun lamtoro dalam ransum dengan perlakuan berbeda-beda.Kenaikan suhu, lingkungan dan anti toksin juga bau menyengat dari tepung daun lamtoro dalam ransum dapat menurunkan ukuran indeks putih telur burung 
puyuh.Hal ini menyebabkan pemberian tepung daun lamtoro dalam ransum burung puyuh tidak memberikan pengaruh yang nyata.

\section{Haugh Unit}

Berikut ini rata-rata HU telur burung puyuh (Coturnix coturnix javonica) pada masing-masing perlakuan dapat dilihat pada tabel dibawah ini.

Tabel 9. Rata-rata HU telur burung puyuh padamasing-masing perlakuan (mm)

\begin{tabular}{|c|c|c|c|c|c|c|c|c|}
\hline \multirow{2}{*}{ Ulangan } & \multicolumn{6}{|c|}{ Perlakuan } & \multirow{2}{*}{ Total } & \multirow{2}{*}{ Rataan } \\
\hline & L0 & L1 & L2 & L3 & $\mathrm{L} 4$ & L5 & & \\
\hline 1 & 63.297 & 62.459 & 63.458 & 61.961 & 65.417 & 66.511 & 383.103 & 63.850 \\
\hline 2 & 60.606 & 63.608 & 64.315 & 64.167 & 64.728 & 63.134 & 380.558 & 63.426 \\
\hline 3 & 64.611 & 64.355 & 64.503 & 61.384 & 62.469 & 62.169 & 379.491 & 63.248 \\
\hline 4 & 62.221 & 65.658 & 63.397 & 62.024 & 61.930 & 64.345 & 379.575 & 63.262 \\
\hline Jumlah & 250.735 & 256.08 & 255.673 & 249.536 & 254.544 & 256.159 & 1522.727 & 253.788 \\
\hline Rataan & 62.684 & 64.02 & 63.918 & 62.384 & 63.636 & 64.034 & 380.681 & 63.446 \\
\hline
\end{tabular}

Rataan keseluruhan diperolehuntuk masing-masing pada perlakuan L0 (Ransum tanpa pemberian tepung daun lamtoro 0\%) dengan rataan Haugh Unit 62.68, pada perlakuan L1 (Ransum dengan pemberian tepung daun lamtoro 5\%) dengan rataan Haugh Unit 64.02, pada perlakuan L2 (Ransum dengan pmberian tepung daun lamtoro 10\%) dengan rataan Haugh Unit 63.92, pada perlakuan L3 (Ransum dengan pemberian tepung daun lamtoro 15\%) dengan rataan Haugh Unit 62.38, pada perlakuan L4 (Ransum dengan pemberian tepung daun lamtoro 20\%) dengan rataan Haugh Unit 63.64, pada perlakuan L5 (Ransum dengan pemberian tepung daun lamtoro 25\%) dengan rataan Haugh Unit 64.03.

Hal ini disebabkan karena nilai Haugh Unit merupakan logaritma terhadap tinggi albumen kemudian disambungkan kedalam nilai koreksi dari fungsi berat telur, sehinga apabila nilai berat telur yang diperoleh berbeda tidak nyata, maka dapat menyebabkan nilai Haugh Unit berbeda tidak nyata, seperti pernyataan Stadelman and Cotterill (1995), menyatakan bahwa faktor yang mempengaruhi nilai Haugh Unit adalah tinggi putih telur dan berat telur.

Hasil penelitian nilai Haugh Unit ini memiliki rata-rata 63.44, sehingga telur puyuh pada penelitian ini tergolong pada kualitas A, sesuai dengan pendapat Yuwanta (2007) telur yang mempunyai nilai $\mathrm{HU}>79$ termasuk kelas AA, nilai $\mathrm{HU}>79>\mathrm{u}>55$ termasuk kelas A, nilai $\mathrm{HU}>55>\mathrm{u}>31$ termasuk kelas $\mathrm{B}$, dan nilai $\mathrm{HU}<31$ termasuk kelas $\mathrm{C}$.

\section{Rekapitulasi Hasil Penelitian}


Dari hasil penelitian, maka dapat dibuat rekapitulasi data yang dapat dilihat pada tabel dibawah ini.

Tabel 10. Rekapitulasi hasil penelitian

\begin{tabular}{cccccc}
\hline \multirow{2}{*}{ Perlakuan } & \multicolumn{5}{c}{ Parameter } \\
\cline { 2 - 6 } & $\begin{array}{c}\text { Berat Telur } \\
\text { (gr) }\end{array}$ & $\begin{array}{c}\text { Ketebalan } \\
\text { kerabang }(\mathrm{mm})\end{array}$ & $\begin{array}{c}\text { Indeks } \\
\text { Kuning Telur }\end{array}$ & $\begin{array}{c}\text { Indeks Putih } \\
\text { Telur }\end{array}$ & $\begin{array}{c}\text { Haugh Unit } \\
(\text { HU) }\end{array}$ \\
\hline L0 & 8.99 & 0.99 & 0.89 & 0.22 & 62.68 \\
L1 & 8.05 & 1.00 & 0.70 & 0.21 & 64.02 \\
L2 & 8.88 & 1.00 & 0.70 & 0.24 & 63.92 \\
L3 & 9.20 & 1.00 & 0.60 & 0.19 & 62.38 \\
L4 & 8.59 & 0.99 & 0.66 & 0.21 & 63.64 \\
L5 & 8.59 & 0.98 & 0.66 & 0.23 & 64.03 \\
\hline
\end{tabular}

Berdasarkan dari hasil tabel rekapitulasi data penelitian diatas dapat dilihat bahwa pemberian tepung daun lamtoro dalam ransum berpengaruh tidak nyata terhadap berat telur,tebal kerabang telur, indeks kuning telur, indeks putih telur, haugh unit (HU) telur burung puyuh (Coturnix-coturnix javonica).

\section{KESIMPULAN}

Berdasarkan kualitas telur burung puyuh pemberian tepung daun lamtoro(Leucaena leucocephala) dalam ransum terhadap kualitas telur burung puyuh (Coturnix-coturnix javonica), tidak memberikan pengaruh terhadap umur bertelur, bobot telur dan tebal kerabang telur,indeks yolk,indeks albumen, tetapi memberikan pengaruh terhadap warna telur dan nilai Haugh Unit (HU) akan tetapi tidak nyata.

\section{DAFTAR PUSTAKA}

Buckle,K,A., R.A. Edwards, G.H. Fleet, and M Wotton. 1987. Ilmu Pangan. Terjamahan: H. Purnomo dan Adiono. Universitas Indonesia Press. Jakarta.

Hanafiah KA. 2003. Rancangan Percobaan : Teori dan Aplikasi. Ed. Revisi, 11. Jakarta: PT Raja Grafindo Persada .

Indratiningsih, R.A. dan Rihastuti. 1996. Dasar Teknologi Hasil Ternak. Susu dan Telur. Gadjah Mada University Press. Yogyakarta.

Listiyowati, E dan K. Roospitasari. 2000. Puyuh Tata Laksana Secara Komersial. Cetakan XI PT. Penebar Swadaya

Mattjik, A.A. \& LM. Sumertajaya. 2002. Perancangan Percobaan dengan Aplikasi SAS dan Minitab. Institut Pertanian Bogor Press, Bogor.

Suprapti, Lies. 2002Penawetan telur. Yogyakarta: Kanisius. 
| JURNAL PETERNAKAN | VOLUME :03 | NO : 01 | TAHUN 2019 | E-ISSN. 2599-1736| 10

Stadelman and Cotterill, 1995, Ketebalan Kerabang Telur. H. Purnomo dan Adiono. Jakarta:UI Press.

Yuwanta, T. 2007. Telur Dan Produksi Telur. Universitas Gajah Mada Press. Yogyakarta. 